\title{
Hard Boiled: Alcohol Use as a Risk Factor for MDMA-Induced Hyperthermia: a Systematic Review
}

\author{
Jan van Amsterdam ${ }^{1}$ (1) $\cdot$ Tibor M. Brunt $^{1} \cdot$ Mimi Pierce $^{1} \cdot$ Wim van den Brink ${ }^{1}$
}

Received: 22 June 2021 / Revised: 7 September 2021 / Accepted: 11 September 2021 / Published online: 23 September 2021

(c) The Author(s) 2021

\begin{abstract}
Although MDMA (ecstasy) is a relatively safe recreational drug and is currently considered for therapeutic use for the treatment of posttraumatic stress disorder (PTSD) and alcohol use disorder (AUD), recreational MDMA use occasionally elicits hyperthermia and hyponatremia, sometimes with a fatal outcome. Specific risk factors for both adverse effects are profuse sweating while vigorously dancing under unfavorable conditions such as high ambient temperatures and insufficient fluid suppletion which result in dehydration. Concomitant use of MDMA and alcohol is highly prevalent, but adds to the existing risk, because alcohol facilitates the emergence of MDMA-induced adverse events, like hyperthermia, dehydration, and hyponatremia. Because of potential health-related consequences of concomitant use of MDMA and alcohol, it is important to identify the mechanisms of the interactions between alcohol and MDMA. This review summarizes the main drivers of MDMA-induced hyperthermia, dehydration, and hyponatremia and the role of concomitant alcohol use. It is shown that alcohol use has a profound negative impact by its interaction with most of these drivers, including poikilothermia, exposure to high ambient temperatures, heavy exercise (vigorous dancing), vasoconstriction, dehydration, and delayed initiation of sweating and diuresis. It is concluded that recreational and clinical MDMA-users should refrain from concomitant drinking of alcoholic beverages to reduce the risk for adverse health incidents when using MDMA.
\end{abstract}

Keywords MDMA $\cdot$ Ecstasy $\cdot$ Alcohol $\cdot$ Interaction $\cdot$ Risk factor $\cdot$ Hyperthermia $\cdot$ Hyponatremia $\cdot$ Fatalities

\section{Introduction}

MDMA (ecstasy, 3,4-methylenedioxymethamphetamine) is a worldwide popular recreational drug. Though serious health incidents have been reported, including fatal cases, their incidence is very low especially considering its widespread use (van Amsterdam et al. 2020). MDMA is usually consumed in dance clubs and raves, frequently in the context of polysubstance use, i.e., MDMA in combination mainly with alcohol (and cannabis) (Barrett et al. 2005; Breen et al. 2006; Degenhardt et al. 2009; Izco et al. 2007; Mohamed et al. 2011; Schifano 2004; Winstock et al. 2001), probably because alcohol is legal and easily accessible in most countries. Around $90 \%$ of all ecstasy users also consume alcohol

Jan van Amsterdam jan.van.amsterdam@amsterdamumc.nl; vanamsterdam@gmx.net

1 Department of Psychiatry, Amsterdam University Medical Center, University of Amsterdam, P.O. Box 22660,

1100 DD Amsterdam, The Netherlands with over 70\% of them at hazardous levels (Morefield et al. 2011; Winstock et al. 2001). In Australia, 65\% of regular ecstasy users reported concomitant use of alcohol and MDMA (Breen, et al. 2006) and 35\% reported concomitant high-risk alcohol use (Kinner et al. 2012). According to the 2001-2002 national epidemiologic survey in the USA, 95\% of MDMA users regularly drink alcohol (Keyes et al. 2008). More recently, MDMA-assisted psychotherapy is considered for the treatment of severe posttraumatic stress disorder (PTSD) (Mitchell et al. 2021) and alcohol use disorder (Sessa et al. 2021), the latter emphasizing the clinical relevance of possible interactions between MDMA and alcohol.

\section{Non-fatal Incidents}

Alcohol was implicated in 75\% of all MDMA-related Emergency Department (ED) presentations in 2008-2010 $(n=236)$ in Australia, which was 5.6-fold more than in GHB-related EDpresentations (Horyniak et al. 2014). Between 2009 and 2019, the Dutch Monitor Drug Incidents (MDI) reported 11,729 adverse health incidents related to the use of ecstasy. The 
proportion of medium to severe intoxications was substantially higher for co-use of MDMA and alcohol (35\%) than for MDMA alone (20\%) (Schürmann et al. 2020; Vercoulen and Hondebrink 2021). In a case-series of MDMA-related ED-visits, 9 out of 48 patients showed hyperpyrexia $\left(>37.1^{\circ} \mathrm{C}\right.$ ) (Williams et al. 1998), and in another sample of 52 ED-patients, $4 \%$ showed hyperthermia (defined as body temperature $>41{ }^{\circ} \mathrm{C}$ ) and $52 \%$ of these patients had used MDMA together with alcohol of whom five patients had severe medical complications and one patient a fatal outcome (Liechti et al. 2005). Grunau et al. have compiled 71 cases (of which 25 were fatal) of MDMA-related hyperpyrexia (Grunau et al. 2010; Liechti et al. 2005). Finally, 17 cases of MDMA-related hyponatremia (in 10 cases analytically confirmed) were identified between 1993 and 1996 by the London center of the National Poisons Information Service with two of them fatal (Hartung et al. 2002). More recently, mild MDMA-related hyponatremia was seen in 9 out of 63 recreational MDMA users during an indoor party (van Dijken et al. 2013).

\section{Fatal Incidents}

Of 495 ecstasy-related deaths in England and Wales between 1997 and 2006, 20\% involved the use of MDMA alone and $30 \%$ MDMA combined with alcohol (Rogers et al. 2009). Alcohol was detected post-mortem in $29-60 \%$, in addition to MDMA, of drug-related fatalities (Forrest 2003; Kaye et al. 2009; Roxburgh and Lappin 2020). However, these figures cannot be converted to a relative risk of co-use of MDMA and alcohol because the absolute prevalence of either MDMA use alone, combined use of MDMA and alcohol, or alcohol use alone cannot be derived from these studies.

\section{Fatalities Reported in Clinical Context}

Only one study (Cohen et al. 2021), covering 1000 reports as part of FDA drug safety surveillance data on the use of MDMA for the treatment of PTSD, presented 62 unique records of the combined use of MDMA and alcohol. This study showed that the risk for a fatal outcome - not per se resulting from hyperthermia - was two-fold higher when MDMA was combined with alcohol compared to the use of MDMA alone (corrected for the use of other substances). However, the incidence such as fatalities was low considering that clinical cases lacking side effects were not reported to the FDA (Food and Drug Administration). Finally, other classes of drugs, like opioids and benzodiazepines, were more often used concomitantly with MDMA than alcohol, but showed (slightly) lower odds ratios for the reported fatalities.

\section{Hyperthermia and Dehydration}

The most frequently seen acute serious adverse effects of recreational MDMA-use are hyperpyrexia (hyperthermia; heatstroke), dehydration, and hyponatremia. In 87 fatal cases related to MDMA and/or related drugs, hyperpyrexia and hyponatremia-related cerebral edema were the two primary causes of death in 30 and 9 cases, respectively (Kalant 2001). Deaths due to hyperthermia involved severe dehydration, rhabdomyolysis, multi-organ failure, renal and liver failure, and disseminated intravascular coagulation (Brown and Osterloh 1987; Docherty and Green 2010; Grunau et al. 2010; Hall and Henry 2006; Liechti et al. 2005; Parrott 2012; Rogers et al. 2009). Hospital presentations of severe hyperthermia in ecstasy users have been frequently reported (Hall and Henry 2006; Patel et al. 2005), although the incidence is relatively low considering its wide-spread use. It remains unclear why moderate hyperpyrexia occasionally progresses to severe hyperthermia (Henry et al. 1992). Most reported cases of MDMA-induced hyperthermia appear to be associated with or facilitated by excessive exertion (vigorous dancing) in warm environments associated with insufficient fluid supplementation, but extreme physical activity is not a requirement for MDMA-induced hyperpyrexia (Hall and Henry 2006). If present, the duration and degree of pyrexia are strong indicators for the mortality risk (Grunau et al. 2010; Hall and Henry 2006; Henry 1992; Liechti 2014) implicating that control of hyperthermia is key to survival (Tehan et al. 1993).

Table 1 shows some risk factors of MDMA-induced (fatal) hyperpyrexia. MDMA-related hyperthermia occurred predominantly in hot nightclubs, which suggest that setting is pivotal for this complication (Henry 1992), and stimulant-driven exertional heatstroke plays a role in MDMA-related hyperthermia. Hyperthermia is, however, also observed following MDMA-exposure outside "rave" party settings in the absence of physical activity (Parrott 2012; Patel, et al. 2005). Dehydration (hypohydration) is another risk factor for and a major cause of hyperthermia. Dehydration results from MDMA-induced vasoconstriction, which halts sweats production, conserves blood volume, and thus leads to an increase in core body temperature. Indeed, recreational MDMA users frequently reported "increased body temperature" (90\%), "increased sweating" (85\%), and "dehydration" (85\%) (Davison and Parrott 1997). Others showed that ecstasy users complained about "overheating/sweating" ( $>60 \%)$ and an "urge to drink/dehydration" (> 80\%) during acute MDMAexposure (Kish et al. 2010) or reported "hot and cold flushes" and "profuse sweating" (39\%) (Topp et al. 1999). In an Internet survey of over 200 recreational users, $31 \%$ 
Table 1 Risk factors of MDMA-induced (fatal) hyperpyrexia

\begin{tabular}{|c|c|}
\hline Risk factors & References \\
\hline Multiple dosing (booster or high doses) & Green et al. (2004); Parrott (2012); Schütte et al. (2013); Topp et al. (1999) \\
\hline $\begin{array}{l}\text { Prolonged and vigorous dancing in hot } \\
\text { settings during "rave" dance parties }\end{array}$ & $\begin{array}{l}\text { Dafters (1995); Docherty and Green (2010); Kiyatkin et al. (2014); Parrott et al. (2006); Suy et al. } \\
\text { (1999); Winstock et al. (2001) }\end{array}$ \\
\hline Reduced fluid intake and dehydration & $\begin{array}{l}\text { Bouchama and Knochel (2002); Coris et al. (2004); Montain and Coyle (1992); Sawka (1992); Sawka } \\
\text { et al. (1985) }\end{array}$ \\
\hline Co-use of MDMA and alcohol & $\begin{array}{l}\text { Calle et al. (2019); Calle et al. (2018); Horyniak et al. (2014); Liechti et al. (2005); Palamar et al. } \\
\text { (2019); Rogers et al. (2009); Roxburgh and Lappin (2020); Schifano (2004); Schifano et al. (2003) }\end{array}$ \\
\hline Hyperthyroidism & Sprague et al. (2018) \\
\hline
\end{tabular}

of the respondents felt moderately hot, and $12 \%$ reported feeling very or extremely hot, when on MDMA (Parrott et al. 2006). A dry mouth/thirst, reported by $25-88 \%$ of recreational MDMA-users (Baylen and Rosenberg 2006), is a predictor of dehydration which predisposes to heat exhaustion, hyperthermia, and heat stroke. Due to MDMAinduced heat production, subjects start shivering and profuse sweating, which is indicative for hyperpyrexia.

As an inhibitor of the secretion of arginine vasopressin $(\mathrm{AVP}=$ antidiuretic hormone $=\mathrm{ADH})$ and as a peripheral vasodilator, which increases diuresis and sweating, respectively, alcohol may facilitate dehydration. This may explain why MDMA-related deaths are more likely to occur when alcohol and other substances are co-ingested (Schifano 2004; Schifano et al. 2003).

In addition to dehydration and heatstroke in dance clubs, MDMA may also cause water retention via stimulation of AVP-release. As a result, MDMA may elicit hyponatremia leading to cerebral edema, which can be fatal, as well. As will be outlined in this review, concurrent use of MDMA and alcohol may increase both the risk of hyperthermia and hyponatremia. Although hyperthermia and hyponatremia are two different syndromes with hyponatremia being less prevalent, hyponatremia may arise from hyperthermia (see Fig. 2). In this review, we provide a summary of the available pre-clinical and clinical information to better understand the possible mechanisms leading to hyperpyrexia and hyponatremia in people concomitantly using MDMA and alcohol with the aim to support the development of prevention and harm-reduction strategies, and to increase the clinical safety of MDMA in future therapeutic applications.

\section{Methods}

A systematic literature review was performed using the PRISMA-protocol to retrieve studies from Medline (PubMed), EMBASE, and PsycINFO. Relevant studies were collected up to May 23, 2021, including articles published or ahead of print from September 2010 to October 2020. Inclusion criteria were as follows: (1) describes the relationship between the combined use of MDMA and alcohol with either hyperthermia, hyponatremia, or AVP-release and (2) data reported full text in either Dutch, English, German, or French. Exclusion criteria were commentaries and case reports. Two researchers ( $\mathrm{JvA}$ and MP) were involved in the selection of appropriate studies, which was executed in two rounds. Initially, 188 studies were retrieved of which 112 unique studies remained after removal of duplicates. These 112 studies were further processed; i.e., title and abstract were screened to determine eligibility applying the inclusion and exclusion criteria mentioned above. In a second round, full texts of 28 selected were checked for eligible studies resulting in the final inclusion of nine papers. Figure 1 shows the PRISMA diagram of the identification, screening, and inclusion of the reports. See figure "Supplementary information" for the search string and PRISMA checklist.

Because the content in the nine selected papers contained limited information on the possible mechanisms related to the combined effect of MDMA and alcohol on hyperthermia and hyponatremia, we also searched the reference lists of three reviews about the interaction between MDMA and alcohol (Mohamed et al. 2011; Papaseit et al. 2020; Vercoulen and Hondebrink 2021) and the reference lists of the papers that were retrieved in our systematic search but were not included. These additional papers provided relevant information to answer our research question.

\section{Results}

First, we describe the results of the systematic research on the interaction between MDMA and alcohol on hyperthermia and hyponatremia ("Effect of Concomitant Alcohol Use on MDMA-Induced Hyperthermia and Hyponatremia"). Then we summarize what is generally known about regulation of body temperature and hydration ("Mechanisms Involved in the Increased Risk of MDMA and Concomitant Alcohol Use"). Finally, we describe the literature on the possible mechanisms involved in the combined effects of MDMA and alcohol on hyperthermia ("Regulation of body Temperature"), dehydration ("Effect of MDMA and/or 
Fig. 1 PRISMA flow diagram. Additional eligible reports were retrieved via the checking of reference list of the selected 78 studies, including the reviews

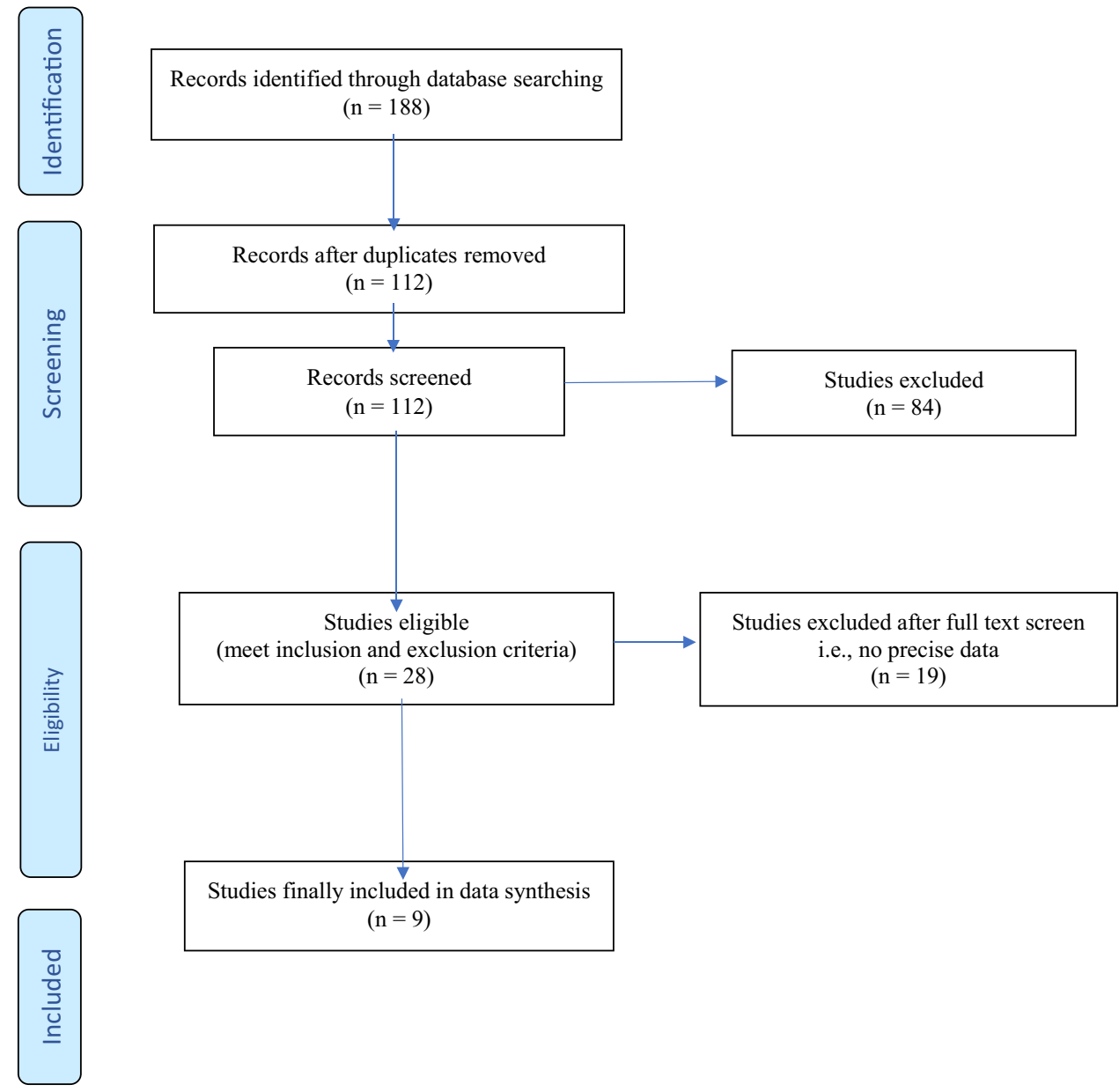

Alcohol on Body Temperature"), and hyponatremia ("Effect of MDMA and/or Alcohol on Hydration").

\section{Effect of Concomitant Alcohol Use on MDMA-Induced Hyperthermia and Hyponatremia}

Table 2 describes the results of the nine studies finally included (one human study and eight rodent studies). Overall, MDMA induced a modest to strong increase in body temperature, which was attenuated by alcohol under normal ambient temperatures, but not under relatively high ambient temperature conditions. In the human study, MDMA-induced minor hyperthermia $\left(+0.4{ }^{\circ} \mathrm{C}\right)$ and this effect tended to be attenuated $(P=0.09)$ by pre-treatment with alcohol (0.6\%o v/v) (Dumont et al. 2010). At ambient temperatures of $21-23{ }^{\circ} \mathrm{C}$, a high dose of ethanol $(1.5 \mathrm{mg} /$ $\mathrm{kg}$ ) attenuated MDMA-induced hyperthermia in rats for several hours (Cassel et al. 2004, 2005; Hamida et al. 2007, 2006, 2008), although in some of these studies, tolerance of the alcohol effect was observed. One rodent study (Cassel et al. 2007) showed that the same dose of MDMA caused a much stronger hyperthermic response at an ambient temperature of $32{ }^{\circ} \mathrm{C}$ compared to an ambient temperature of $23{ }^{\circ} \mathrm{C}$ and that the concomitant use of alcohol had no attenuating effect at high ambient temperatures. Similarly, pre-treatment with alcohol at a high ambient temperature $\left(30{ }^{\circ} \mathrm{C}\right)$ did not attenuate the hyperthermic effect of MDMA in humans (Izco et al. 2007). Finally, it is of interest that all rodents treated with MDMA (6.6 mg/kg i.p.) at $32{ }^{\circ} \mathrm{C}$ died after $120 \mathrm{~min}$, whereas no lethality was observed with the same dose of MDMA at $23{ }^{\circ} \mathrm{C}$ (Cassel et al. 2007). In summary, these studies show that alcohol has an attenuating effect MDMA-induced hyperthermia in humans and rodents in rest and under normal ambient temperatures. In contrast, at (relatively) high ambient temperatures and during exercise, MDMA induced serious and often fatal hyperthermia in rodents which were not prevented or attenuated by concomitant use of alcohol (see Table 2; "Effect of MDMA and/or Alcohol on Hydration"). Table 2 also shows that no data were found about the effect of concomitant alcohol use on MDMA-induced hyponatremia. 


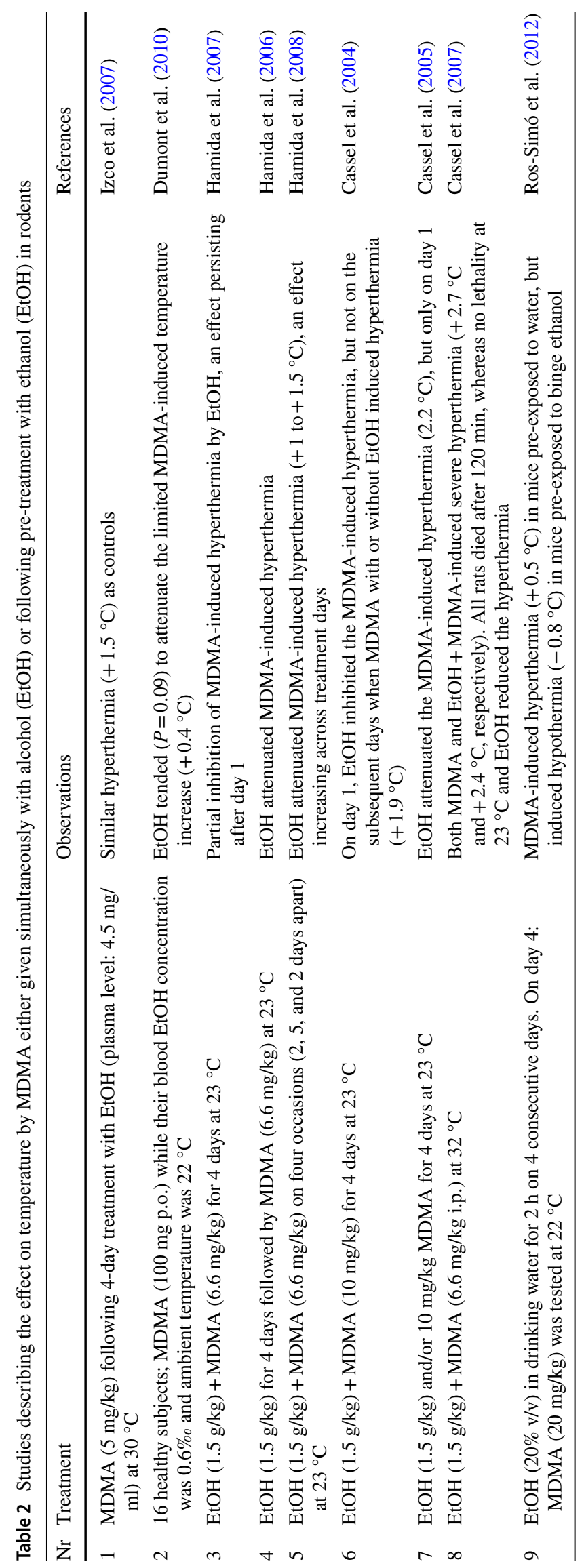




\section{Mechanisms Involved in the Increased Risk of MDMA and Concomitant Alcohol Use}

Hyperthermia, dehydration, and over-hydration (i.e., hyponatremia) are the main causes of MDMA-related lifethreatening events or even death (Kalant 2001). MDMA may induce hyponatremia without symptoms of hyperpyrexia, but hyponatremia can also be elicited secondary to hyperpyrexia. Below we will further elaborate on the propagating and facilitating effects of alcohol on MDMA-induced hyperthermia and hyponatremia which explain the increased risk of the combined use of MDMA and alcohol. The various determinants involved in MDMA-induced hyperthermia and hyponatremia are summarized in Table 3 and some of the mechanisms are depicted in Fig. 2. Figure 2 outlines that although concomitant alcohol use may have an attenuating effect of MDMA-induced hyperthermia (previous paragraph), it may - under certain conditions - have detrimental effects on both MDMA-induced hyperthermia and hyponatremia.

\section{Regulation of body Temperature}

\section{Balance Between Heat Production and Dissipation}

Hyperthermia (heat stroke) emerges from an imbalance between the accumulation of heat generated in and the capacity to dissipate heat from the body. Heat is dissipated in humans by peripheral vasodilatation and sweating. Evaporation of $1 \mathrm{ml}$ of sweat from the skin represents the loss of approximately $0.58 \mathrm{kcal}$ (Murray 1996). In a hot environment, the sweat rate can exceed $2500 \mathrm{~mL} / \mathrm{h}$ (Sawka and Pandolf 1990), which equals a heat dissipation rate of $1450 \mathrm{kcal} / \mathrm{h}(6000 \mathrm{~kJ} / \mathrm{h})$. As such, sweating represents a rapid and huge heat transfer to the environment. In response to massive water loss due to sweating, AVP is secreted from the pituitary gland. It is interesting to note that rodents miss the capacity to sweat.

\section{Thermoregulation}

Humans are homeothermic animals, and their (core) temperature is relatively stable under changing ambient temperatures. Temperature regulation in man is under control of the thermoregulatory center in the hypothalamus. Hyperthermia typically involves a failure or disruption of this control system. Poikilothermic (poikilos means "manifold") agents render subjects poikilothermic, whereby they tend to equilibrate their body temperature with the ambient temperature they are in. Under such conditions, a cool environment results in hypothermia and a warm environment in hyperthermia. As explained below, both MDMA and alcohol are poikilothermic agents, i.e., agents that disrupt the thermoregulatory control system.

Only organs of sufficient metabolic capacity, like brown adipose tissue (BAT) and skeletal muscle (SKM), can generate large amounts of heat (thermogenesis). For example, rapid muscle contraction or shivering generates considerable heat in SKM, but such shivering is energetically costly and impractical to sustain for extended periods of time. However, excessive heat production in BAT and SKM (tremors, muscle cramping) causes hyperthermia which in turn increases the risk of organ damage (Rosenberg et al. 1986; Rusyniak and Sprague 2006). BAT is densely innervated by sympathetic neurons, and the binding of noradrenaline (NA) to $\beta_{3}$-adrenoceptors, predominantly present in adipose tissue (Skeberdis 2004), is most significant for thermogenesis (Cannon and Nedergaard 2004; Dao et al. 2014). NA can also stimulate alpha ${ }_{1}$-adrenoceptors causing vasoconstriction so that heat dissipation via the skin is blocked and body temperature is increased (Mills et al. 2004; Zhao et al. 1997). Due to excessive dancing under the influence of MDMA, SKM generates heat in the muscles on top of that produced by BAT (Liechti 2014). The concomitant increase in heartbeat and blood flow generates even more heat.

MDMA, a potent noradrenaline and serotonin reuptake inhibitor, has shown to promote thermogenesis and

Table 3 Determinants putatively involved in MDMA-induced hyperthermia or hyponatremia

\begin{tabular}{|c|c|c|c|}
\hline & Determinant & Result & References \\
\hline 1 & $\begin{array}{l}\text { Dysregulation of the } \\
\text { thermoregulatory system } \\
\text { (poikilothermia) }\end{array}$ & Hyperpyrexia at high ambient temperature & Docherty and Green (2010); Rusyniak et al. (2008) \\
\hline 2 & $\begin{array}{l}\text { Warm ambient temperature } \\
\text { and heavy exercise (vigorous } \\
\text { dancing) }\end{array}$ & $\begin{array}{l}\text { Increased heat generation in adipose tissue and } \\
\text { skeletal muscles }\end{array}$ & Mills et al. (2003); Rusyniak et al. (2005) \\
\hline 3 & Peripheral vasoconstriction & Reduced peripheral blood flow $>$ lower heat dissipation & Gordon et al. (1991); Pedersen and Blessing (2001) \\
\hline 4 & Water management in the body & $\begin{array}{l}\text { If dehydrated, less water available for sweating. } \\
\text { Dehydration via inhibition of AVP-release by } \\
\text { diuretics, like alcohol, caffeine (and MDMA) }\end{array}$ & $\begin{array}{l}\text { Camarasa et al. (2006); Vanattou-Saïfoudine et al. } \\
\text { (2012) }\end{array}$ \\
\hline
\end{tabular}




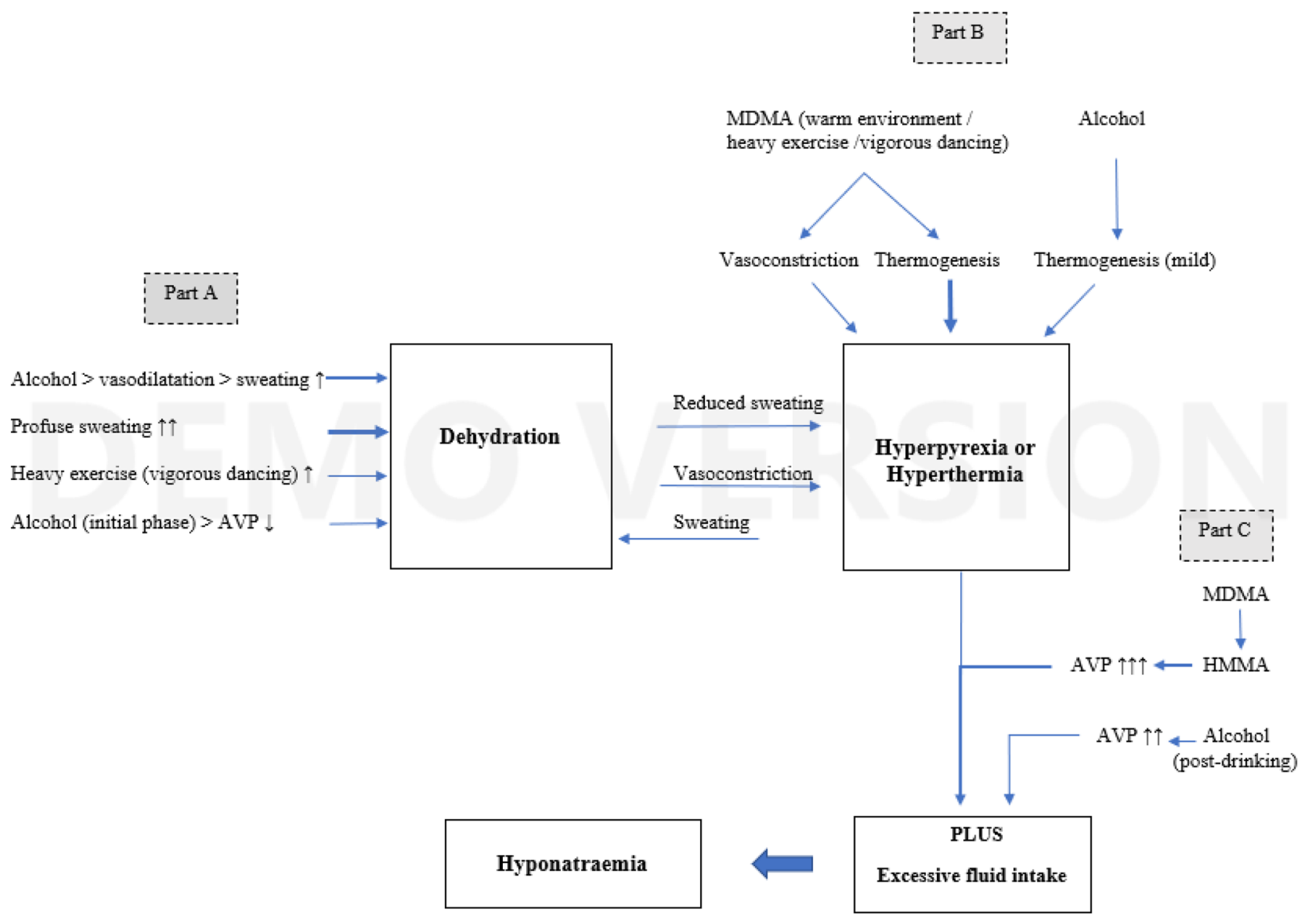

Fig. 2 Mechanisms involved in hyperthermia and hyponatremia induced by MDMA and alcohol. Part A: sweating and vigorous dancing results in heavy sweating and dehydration. Dehydration is further increased by increased sweating as a result of vasodilatation and reduced AVP-secretion (arginine vasopressin) by alcohol. Hyperpyrexia results from (a) dehydration-induced reduced sweating and vasoconstriction in dehydrated subjects and, as depicted in Part

to induce hyperthermia. This is presumably mainly caused by increased sympathetic outflow, considering that carvedilol, an antagonist of both $\alpha_{1}$ and $\beta_{3}$-adrenoreceptors and the $\beta_{3}$-adrenoreceptor blocker cyano-pindolol, but not nonselective $\left(\beta_{1}+\beta_{2}\right)$ adrenoceptor antagonists, attenuates the MDMA-induced increase in body temperature (Hysek et al. 2012, 2013; Kiyatkin et al. 2016; Sprague et al. 2005). For instance, the increased in rectal temperature $\left(+3.6{ }^{\circ} \mathrm{C}\right)$ by MDMA (40 mg/kg, s.c.) was inhibited by the $\alpha_{1}$-adrenergic antagonist prazosin together with the $\beta_{3}$-adrenergic antagonist SR59230A (Bexis and Docherty 2009; Sprague et al. 2004). In addition, MDMA induced peripheral vasoconstriction, limiting heat dissipation (Gordon et al. 1991; Pedersen and Blessing 2001).

The role of serotonin (5-HT) in thermoregulation is more complicated with amongst others the $5-\mathrm{HT}_{2 \mathrm{~A}}$ receptor as a key factor in the development of hyperthermia (Herin
B, MDMA induced vasoconstriction and thermogenesis (under unfavorable conditions). Part C: HMMA (4-hydroxy-3-methoxy-methamphetamine), the major metabolite of MDMA, is a potent releaser of AVP. In addition to hyperthermia, the increased secretion of AVP, by both alcohol and MDMA, is responsible for excessive fluid intake leading to hyponatremia

et al. 2005). Serotonin, released by the hypothalamus (De Fanti et al. 2000) or direct injection of serotonin into the hypothalamus, activates thermogenesis in BAT (Cannon and Nedergaard 2004) resulting in hyperthermia (Ishiwata et al. 2017). Studies using dopamine antagonists have also indicated the involvement of dopamine in MDMA-induced hyperthermia (Rusyniak et al. 2008). Furthermore, antagonists of both $5-\mathrm{HT}_{2 \mathrm{~A}}$ and $\mathrm{D}_{1}$ receptors counteract at the level of the hypothalamus the MDMA-induced hyperthermia (Vanattou-Saïfoudine et al. 2010).

The excessive heat produced (i.e., hyperthermia) disturbs intracellular biochemical signaling throughout the body resulting in devastating medical complications, including multiple organ failure, renal failure, metabolic acidosis, liver failure, intravascular coagulation, and/or rhabdomyolysis (breakdown of damaged skeletal muscle), which may be fatal. Interestingly, most drugs that protect against 
MDMA-induced neurotoxicity in rodents either cause hypothermia or prevent MDMA-induced hyperthermia (Colado et al. 1999a, b; Colado et al. 1998, 2001; Colado et al. 1999a, b), suggesting that dysregulation of thermoregulation by MDMA is a crucial element of its neurotoxicity.

\section{Hydration}

MDMA is also a fascinating drug from a hydration physiology perspective, because it can cause the typical symptoms of dehydration, like thirst and dry mouth, whereas it causes hyperhydration on a cellular level. Moreover, dehydration is an important factor in the development of hyperthermia in recreational MDMA users who vigorously dance at relatively high ambient temperatures (Henry 1992; Patel et al. 2005; Tehan et al. 1993). The high sweat rates required to sustain heat loss during exercising/dancing at $25-35{ }^{\circ} \mathrm{C}$ (Desruelle et al. 1996) inevitably lead to dehydration, unless sufficient fluid is ingested to supplement the volume of sweat lost. For every $1 \%$ of body weight lost (equivalent to around $700 \mathrm{ml}$ of sweat) during exercise, the core body temperature increases by $0.15-0.23{ }^{\circ} \mathrm{C}$ (Coris et al. 2004; Sawka 1992). Body fluid losses of around $8 \%$ of body mass (equivalent to 5-6 L of sweat) are hazardous and may become fatal if it exceeds this percentage (Grandjean et al. 2003). The magnitude of dehydration accrued after $2 \mathrm{~h}$ of exercise at an ambient temperature of $33{ }^{\circ} \mathrm{C}$ (no supplementation, and fluid supplementation: $81,48,20 \%$ ) was linearly related with an increase in body temperature (38.4 to $39.1^{\circ} \mathrm{C} ; r=0.98$ ) (Montain and Coyle 1992). Similarly, Graham et al. (2020) showed that rectal temperature increased by $1.1^{\circ} \mathrm{C}$ following exercise for $180 \mathrm{~min}$ at an ambient temperature of $40{ }^{\circ} \mathrm{C}$, if no fluid was supplemented during exercise. Being dehydrated during exercise at $35^{\circ} \mathrm{C}$ resulted in a body temperature of nearly $39^{\circ} \mathrm{C}$, which was considerably higher than in euhydrated subjects (Nadel et al. 1980). Core temperature increased with severity of dehydration, and sweating rate was inversely associated with severity of dehydration (Sawka et al. 1985). Dehydration of approximately 2-3\% of body mass routinely occurs in healthy subjects during intermittent high-intensity exercise, especially when the ambient temperature is high (Galloway 1999). Upon dehydration, sweat rate considerably decreases, which in turn may increase body temperature.

MDMA-induced hyperthermia resembles heatstroke (body temperature $\geq 40.0^{\circ} \mathrm{C}$ ) as observed in athletes running a marathon on warm summer days. Using a simple wrist pedometer, it was shown that an ecstasy user "danced" during one night in the club around $40 \mathrm{~km}$ which is virtually the distance of a marathon ( $\mathrm{WvdB}$, personal communication). Some $60-80$ out of 36,000 marathon athletes were transferred to ED in 2019, because of overheating during a half marathon in Amsterdam on a warm day $\left(24-25^{\circ} \mathrm{C}\right)$ in 2019
(Het Parool 2019). Dehydrated patients may have excessive thirst (Pfennig and Slovis 2012), but the thirst stimulus may not occur until the patient is already $5 \%$ dehydrated (AAP 2000), because the response to thirst is desensitized during conditions of physiologic stress. The apparent lack of or delayed awareness of thirst under such conditions therefore facilitates further dehydration and further increases the risk of serious complications (Cole and Sumnall 2003).

Dehydration is commonly accompanied by diminished diuresis (Pfennig and Slovis 2012). AVP serves to limit unnecessary water loss from the body, especially under hot environmental conditions or when much heat is generated by the body. Exposure of humans for $2 \mathrm{~h}$ in an environment of $50{ }^{\circ} \mathrm{C}$ increased AVP levels from 1.6 to $5.2 \mu \mathrm{U} / \mathrm{ml}$ (Segar and Moore 1968), explaining why men performing work in a hot environment reduced their urine flow, while sweat loss was initially about one liter per hour and water was drunk ad libitum (Weiner 1945).

In summary, dehydration promotes exercise induced hyperpyrexia at high ambient temperatures which coincides with stimulated AVP-secretion.

\section{Effect of MDMA and/or Alcohol on Body Temperature}

\section{Human Studies}

In humans, some placebo-controlled studies performed at normal ambient temperature showed that MDMA did not increase body temperature, whereas other studies showed a modest elevation of body temperature (Dumont and Verkes 2006; Freedman et al. 2005; Liechti 2014; Liechti et al. 2001; Parrott 2012). Pooled data analyses showed that administration of $125 \mathrm{mg}$ MDMA in a controlled laboratory setting produced an acute and dose-dependent elevation in core body temperature in healthy subjects (Liechti 2014). Importantly, these experiments were performed in subjects at rest and at a mean ambient temperature of $22.7 \pm 0.6{ }^{\circ} \mathrm{C}$. This increase in body temperature is rather small (range $\left.0.2-0.8^{\circ} \mathrm{C}\right)$ and did not result in hyperpyrexia $\left(>40.0^{\circ} \mathrm{C}\right)$. However, a substantial number of the subjects (23\%) showed moderate hyperpyrexia $\left(>38.0{ }^{\circ} \mathrm{C}\right)$, demonstrating that MDMA may induce moderate hyperpyrexia even in the absence of any risk factors and at normal ambient temperature $\left(23^{\circ} \mathrm{C}\right)$ (Liechti 2014). Freedman et al. (2005), studying the physiological effects of MDMA at cold $\left(18^{\circ} \mathrm{C}\right)$ and warm $\left(30^{\circ} \mathrm{C}\right)$ ambient temperatures, showed that MDMA $(2 \mathrm{mg} / \mathrm{kg})$ increased in both warm and cold conditions a similar increase in body temperature $\left(0.3-0.6{ }^{\circ} \mathrm{C}\right)$. In general, at low doses and at moderate ambient temperatures, alcohol is known to induce in humans hypothermia (Huttunen et al. 1998) and vasodilatation (Wasielewski and Holloway 2001) with the latter effect responsible for the warm sensation. 
However, at higher doses and relatively high ambient temperatures, alcohol may cause hyperthermia (Kalant and Lê 1983). Alcohol is therefore referred to as a poikilothermic agent, a substance that causes maladaptation of the body to either cold or warm conditions. The only human study on the concomitant use of MDMA and alcohol showed that - at normal ambient temperature $\left(22{ }^{\circ} \mathrm{C}\right)$ - alcohol tended $(p=0.09)$ to attenuate the limited MDMA-induced increase in body temperature (Dumont et al. 2010).

\section{Rodent Studies}

Rats repeatedly (3 times) treated with MDMA (4 mg/kg i.p.) showed a larger hyperthermic response $\left(+2.6{ }^{\circ} \mathrm{C}\right)$ at $30^{\circ} \mathrm{C}$ compared to $19^{\circ} \mathrm{C}\left(+1.3^{\circ} \mathrm{C}\right)$ (Sanchez et al. 2004). Ambient temperature $\left(11,24\right.$, or $\left.30^{\circ} \mathrm{C}\right)$ significantly affected the magnitude of the hyperthermia induced by $2.5-7.5 \mathrm{mg} / \mathrm{kg}$ MDMA with hyperthermia $\left(+4{ }^{\circ} \mathrm{C}\right.$ at $\left.7.5 \mathrm{mg} / \mathrm{kg}\right)$ only observed at $30{ }^{\circ} \mathrm{C}$ (Dafters 1995). MDMA (2.5-7.5 mg/kg) induced hypothermia in rats previously living at $11^{\circ} \mathrm{C}$ (Dafters 1994). Other rodent studies employed very high doses which produced hyperthermia and high levels of morbidity and neurotoxicity (Miller and O'Callaghan 1994). For instance, MDMA (30 mg/kg s.c.) increased colonic temperature by $3.2^{\circ} \mathrm{C}$ at $30{ }^{\circ} \mathrm{C}$, but there was no change at $20^{\circ} \mathrm{C}$ (Gordon et al. 1991); at $10^{\circ} \mathrm{C}$, it even induced hypothermia $\left(-2.0^{\circ} \mathrm{C}\right)$. MDMA $(20$ or $40 \mathrm{mg} / \mathrm{kg}$ ) induced hypothermia in rats at 20 and $22^{\circ} \mathrm{C}$, but hyperthermia at 28 and $30{ }^{\circ} \mathrm{C}$ (Malberg and Seiden 1998). MDMA at a moderate non-toxic dose of $9 \mathrm{mg} / \mathrm{kg}$, s.c. induced relatively weak hyperthermia under standard conditions (quiet rest $22-23{ }^{\circ} \mathrm{C}$ ), but severe hyperthermia in warm environments $\left(29^{\circ} \mathrm{C}\right.$ ) (Brown and Kiyatkin 2004; Kiyatkin et al. 2014). These observations show that MDMA, like alcohol, is a poikilothermic agent. The most robust hyperthermia was found during social interaction versus no social interaction of rats treated with MDMA $(9 \mathrm{mg} / \mathrm{kg}):+2.4{ }^{\circ} \mathrm{C}$ versus $+0.95{ }^{\circ} \mathrm{C}$. At $29^{\circ} \mathrm{C}$, MDMA increased brain temperatures to fatal values $\left(42.2^{\circ} \mathrm{C}\right.$ ) versus an increase to $37.7^{\circ} \mathrm{C}$ at $22-23^{\circ} \mathrm{C}$ : lethality was found for all 6 tested rats under this condition within $6 \mathrm{~h}$ post-injection. In rats, the combination of warm temperature $\left(32{ }^{\circ} \mathrm{C}\right)$ and physical activity (treadmill) increased the body temperature more pronounced $\left(+4.4{ }^{\circ} \mathrm{C}\right)$ than each factor alone $\left(+0.4\right.$ and $+1.8^{\circ} \mathrm{C}$, respectively). This synergistic effect was blocked by the 5- $\mathrm{HT}_{2 \mathrm{~A}}$ receptor antagonist M100907, but not by the $5-\mathrm{HT}_{1 \mathrm{~A}}$ receptor antagonist WAY100635 (Tao et al. 2015). Pre-treatment with an inhibitor of serotonin synthesis, the serotoninergic antagonist methysergide, or the $5-\mathrm{HT}_{1 \mathrm{~A}}$ antagonist WAY 100635 in rats at $30^{\circ} \mathrm{C}$ prolonged the MDMA (5 mg/kg i.p.) induced hyperthermia (Saadat et al. 2005). From this result, it was concluded that diminished 5-HT function leads to an inability to control core temperature in rats under influence of MDMA at high ambient temperatures. This is consistent with the theory that detrimental effects on
5-HT nerve endings result in an increase in body temperature, due to dopamine which is no longer sufficiently abated by the 5-HT system (Green et al. 2004a, b). An interesting result in this regard was found in a study into the combined effects of alcohol and MDMA, whereby exposure to alcohol worsened MDMA's effects on the 5-HT system, reducing 5-HT transporter density (Izco et al. 2007). At relatively high ambient temperature $\left(33-42{ }^{\circ} \mathrm{C}\right)$, alcohol $(0.36-0.54 \mathrm{~g} / \mathrm{kg}$ body weight) was found to modestly increase body temperature (around $+1.0^{\circ} \mathrm{C}$ ) (Allison and Reger 1992).

In the few rodent studies that were presented before (Table 2), alcohol had an attenuating effect on MDMAinduced hyperthermia in rodents in rest and under normal ambient temperatures. However, the serious and occasional fatal hyperthermia following MDMA administration seen in rodents under (relatively) high ambient temperatures and during exercise were not prevented or attenuated by alcohol.

\section{Effect of MDMA and/or Alcohol on Hydration}

AVP is normally released in response to a drop in blood volume or a rise in plasma osmolality and acts to conserve water via inhibition of diuresis. MDMA stimulates the secretion of AVP, resulting in higher plasma AVP levels accompanied by a small decrease in serum sodium (de la Torre et al. 2004; Fallon et al. 2002; Forsling et al. 2001; Henry et al. 1998). It is, however, unclear whether this is a direct effect of MDMA or an effect secondary to MDMA-induced hyperthermia (Dowling et al. 1987; Forsling et al. 2001; Henry et al. 1998, 1992). HMMA (4-hydroxy-3-methoxymethamphetamine), the major metabolite of MDMA, is about two-fold more potent than MDMA in releasing AVP (Fallon et al. 2002) which may explain why AVP-secretion peaks relatively late: 1-2 $\mathrm{h}$ after MDMA ingestion (Forsling et al. 2001). This lagtime may be relevant for the effect of concomitant alcohol use later in an MDMA-session when alcohol is used in the comedown phase. In contrast to MDMA, alcohol shows a biphasic effect on AVP-secretion: alcohol ( $>4 \% \mathrm{w} / \mathrm{v})$ initially inhibits AVP-secretion (Roberts 1963; Rubini et al. 1955; Shirreffs and Maughan 1997), but 30-60 min after alcohol consumption $(1.5 \mathrm{~g} / \mathrm{kg}$ in $6 \mathrm{~h} ; 27 \mathrm{mM})$, it inhibits plasma AVP secretion i.e., a decrease from 5.7 to $3.3 \mathrm{ng} / \mathrm{L}$ within $30 \mathrm{~min}$, but increased to $17 \mathrm{ng} / \mathrm{L}$ at $6 \mathrm{~h}$ post-alcohol consumption. As a result, alcohol consumption results in a net loss of $900 \mathrm{~mL}$ water within $2 \mathrm{~h}$ (Eisenhofer and Johnson 1982; Leppäluoto et al. 1992).

\section{Effect of MDMA and/or Alcohol on Hyponatremia}

Synthetic phenethylamines such as cathinones and amphetamines, including met-amphetamine and MDMA, are known for their induction of hyponatremia. The mechanisms involved in this effect of MDMA and possible the 
Table 4 Mechanisms and additional facilitating factors involved in the pathogenesis of MDMA-associated hyponatremia (Campbell and Rosner 2008; Faria et al. 2020)

\begin{tabular}{ll}
\hline Major mechanisms & Facilitating factors \\
\hline$\bullet$ MDMA-induced secretion of AVP & $\bullet$ False advice to drink a lot of fluids at rave par- \\
ties
\end{tabular}

preventive measures have been recently reviewed by Faria et al. (2020). Hyponatremia (serum sodium $<130 \mathrm{mEq} / \mathrm{L}$; low serum osmolality) is a potentially fatal complication associated with MDMA use (Faria et al. 2020; Ghatol and Kazory 2012) and results from increased AVP secretion caused by the MDMA metabolite HMMA. The mechanism and facilitating factors of hyponatremia are summarized in Table 4. A dry mouth and the sensation of thirst are common side-effects of MDMA-induced hyperthermia, which easily results in fluid overconsumption (Campbell and Rosner 2008). However, after a certain lag time following MDMA use, MDMA is metabolized to HMMA which stimulates AVP-secretion. Similarly, alcohol stimulates AVP a few hours following consumption, i.e., some hours after the last consumption of alcohol. At that moment, excessive intake of hypotonic liquids to subside thirst and overheating can easily result in hyponatremia and ultimately in cerebral edema. Increased exertion, compounded by MDMA-induced hyperthermia, may be held responsible for significant sweat sodium losses and thus hyponatremia. Hyponatremia symptoms range from headaches and ataxia to seizures, decreased levels of consciousness and, in some instances, death from cerebral herniation, a pattern closely resembling that of severe heatstroke resulting from physical exertion at high ambient temperatures (Ginsberg et al. 1970). It should be noted, however, that in most MDMA-induced hyponatremia cases, hyponatremia was not associated with hyperthermia.

"Chill-out" rooms at dance events, where the ambient temperature is relatively low and water and sports drinks are readily available, are primarily designed to limit MDMA-induced hyperthermia. To rehydrate following profuse sweating, subjects should drink water or juice to supplement the lost fluid and the consumption of diuresis promoting drinks. High caffeinated energy drinks are, however, discouraged for rehydration, because they may exacerbate MDMA-induced hyperthermia (Camarasa et al. 2006; Vanattou-Saïfoudine et al. 2012).

\section{Summary and Conclusion}

The various determinants putatively involved in MDMAinduced hyperthermia that are currently outlined may explain that - under certain conditions (e.g., high ambient temperature, heavy exercise) - alcohol use poses an increased health risk when concomitantly used with MDMA. Like MDMA, alcohol is a poikilothermic agent, and both substances may generate heat at high ambient temperatures in an uncontrolled manner. This implies that the additional modest increase of thermogenesis by alcohol, as observed at relatively high ambient temperatures, is no longer adequately downregulated by the thermo-control center in the hypothalamus. In addition, several studies have indicated that adverse hyperthermia-related incidents mainly occur following vigorous dancing and sweating at high ambient temperatures. This is partly due to dehydration occurring under such unfavorable conditions, and severely endangering the maintenance of normal body temperature. Because of their euphoric effects, both alcohol and MDMA may promote vigorous dancing at parties. Moreover, MDMA may delay the initiation of sweating, resulting in an above normal increase of body temperature before sweating commenced (Freedman et al. 2005), while alcohol has no effect on sweating delay. Furthermore, alcohol induces peripheral vasodilatation which counteracts the vasoconstrictive effect of MDMA. Individuals using MDMA may become dehydrated and should be drinking water or juice to supplement lost fluids. Drinking alcohol is, however, not helpful, because it results in a further loss of body fluids. Evidently, antidiuretic drugs (including alcohol and caffeine-containing energy drinks) further promote water loss, dehydration, and hyperpyrexia. In this respect, it is of interest that the diuretic drug caffeine failed to alter body temperature, but it potentiated MDMA-induced hyperthermia and significantly increased MDMA lethality (from 22 to $34 \%$ ) (Camarasa et al. 2006). Alcohol, at least in the initial phase of its consumption, shows a clear antidiuretic effect which promotes hyperpyrexia. In the second phase, alcohol promotes dehydration via (profuse) sweating due to its vasodilatory effect. Dehydration itself may induce vasoconstriction and may as such facilitate MDMA-induced vasoconstriction and hyperpyrexia. In the second phase, alcohol, like MDMA or rather the MDMA-metabolite HMMA, increases AVP production, which may further increase MDMA-induced (severe) hyponatremia.

Both noradrenergic, dopaminergic, and serotoninergic pathways are involved in thermogenesis. MDMA, as 
a re-uptake inhibitor of these monoamines, may therefore induce profound hyperthermia. The increase in body temperature induced by MDMA is not corrected by thermo-control mechanisms, because MDMA behaves as a poikilothermic substance, implying that such control mechanisms are disrupted. Alcohol, also a poikilothermic substance, may, via its effects on various actors, like dehydration, high ambient temperatures, heavy exercise (vigorous dancing) and vasoconstriction, increase the adverse health effects of MDMA.

It is concluded that recreational users of MDMA should be aware of the risk of concomitant drinking of alcoholic (and caffeinated) beverages for adverse health incidents. This is particularly for the use of this combination under unfavorable environmental conditions, such as high ambient temperatures. Given the low incidence of serous side events seen in recreational users, the controlled clinical use of MDMA seems relatively safe. Still, it is advocated to consider the risk factors currently identified when MDMA is clinically used. This study has some limitations. Firstly, only one of the nine studies about the direct interaction of MDMA and alcohol on hyperthermia, retrieved by the systematic search (cf. Table 2), was performed in humans and the remaining eight studies were performed in rats. This is valuable and relevant, because, in contrast to mice, rats' physiological and pharmacological pathways resemble more that of humans, implicating that these data are relevant for the human situation. Secondly, the mechanistic studies underlying the conclusions (risks under adverse circumstances) are not based on (a) studies retrieved by a systematic search and (b) only rarely provided direct evidence from observations related to the interaction between the alcohol and MDMA on the main outcomes. As such, the conclusions are based to a large extent on assumptions regarding a combined effect of both agents.

Supplementary Information The online version contains supplementary material available at https://doi.org/10.1007/s12640-021-00416-z.

Author Contribution JvA and MP performed the systematic search, and JvA, TMD, MP, and WvdB drafted the paper.

\section{Declarations}

Statement of Ethics The paper is exempt from ethical committee approval.

Conflict of Interest WvB reports personal fees from Lundbeck, Novartis, D\&A Pharma, Takeda, Mundipharma, Angelini, Opiant, Idivior, Kinnov Therapeutics, and Camurus for services outside the submitted work. JvA, $\mathrm{TMB}$, and MP report no conflict of interest. The authors have no relevant affiliations or financial involvement with any organization or entity with a financial interest in or financial conflict with the subject matter or materials discussed in the manuscript. This includes employment, consultancies, honoraria, stock ownership or options, expert testimony, grants or patents received or pending, or royalties.
Open Access This article is licensed under a Creative Commons Attribution 4.0 International License, which permits use, sharing, adaptation, distribution and reproduction in any medium or format, as long as you give appropriate credit to the original author(s) and the source, provide a link to the Creative Commons licence, and indicate if changes were made. The images or other third party material in this article are included in the article's Creative Commons licence, unless indicated otherwise in a credit line to the material. If material is not included in the article's Creative Commons licence and your intended use is not permitted by statutory regulation or exceeds the permitted use, you will need to obtain permission directly from the copyright holder. To view a copy of this licence, visit http://creativecommons.org/licenses/by/4.0/.

\section{References}

AAP (2000) American Academy of Pediatrics (AAP). Climatic heat stress and the exercising child and adolescent. Committee on Sports Medicine and Fitness. Pediatrics 106:158-159

Allison TG (1985) Reger, WE 1992 Thermoregulatory, cardiovascular, and psychophysical response to alcohol in men in 40 degrees $\mathrm{C}$ water. J Appl Physiol 72:2099-2107

Barrett SP, Gross SR, Garand I, Pihl RO (2005) Patterns of simultaneous polysubstance use in Canadian rave attendees. Subst Use Misuse 40:1525-1537

Baylen CA, Rosenberg H (2006) A review of the acute subjective effects of MDMA/ecstasy. Addiction 101:933-947

Bexis S, Docherty JR (2009) Role of alpha 1- and beta 3-adrenoceptors in the modulation by SR59230A of the effects of MDMA on body temperature in the mouse. Br J Pharmacol 158:259-266

Bouchama A, Knochel JP (2002) Heat stroke. N Engl J Med 346:1978-1988

Breen C, Degenhardt L, Kinner S et al (2006) Alcohol use and risk taking among regular ecstasy users. Subst Use Misuse 41:1095-1109

Brown C, Osterloh J (1987) Multiple severe complications from recreational ingestion of MDMA ('Ecstasy'). JAMA 258:780-781

Brown PL, Kiyatkin EA (2004) Brain hyperthermia induced by MDMA (ecstasy): modulation by environmental conditions. Eur J Neurosci 20:51-58

Calle P, Maudens K, Lemoyne S et al (2019) Lessons to be learned from toxicological analyses in intoxicated patients and seized materials at an electronic music dance festival. Forensic Sci Int 299:174-179

Calle P, Sundahl N, Maudens K et al (2018) Medical emergencies related to ethanol and illicit drugs at an annual, nocturnal, indoor, electronic dance music event. Prehosp Disaster Med 33:71-76

Camarasa J, Pubill D, Escubedo E (2006) Association of caffeine to MDMA does not increase antinociception but potentiates adverse effects of this recreational drug. Brain Res 1111:72-82

Campbell GA, Rosner MH (2008) The agony of ecstasy: MDMA (3,4-methylenedioxymethamphetamine) and the kidney. Clin J Am Soc Nephrol 3:1852-1860

Cannon B, Nedergaard J (2004) Brown adipose tissue: function and physiological significance. Physiol Rev 84:277-359

Cassel JC, Ben Hamida S, Jones BC (2007) Attenuation of MDMAinduced hyperthermia by ethanol in rats depends on ambient temperature. Eur J Pharmacol 571:152-155

Cassel JC, Jeltsch H, Koenig J, Jones BC (2004) Locomotor and pyretic effects of MDMA-ethanol associations in rats. Alcohol 34:285-289

Cassel JC, Riegert C, Rutz S et al (2005) Ethanol, 3,4-methylenedioxymethamphetamine (ecstasy) and their combination: long-term behavioral, neurochemical 
and neuropharmacological effects in the rat. Neuropsychopharmacol 30:1870-1882

Cohen IV, Makunts T, Abagyan R, Thomas K (2021) Concomitant drugs associated with increased mortality for MDMA users reported in a drug safety surveillance database. Sci Rep 11:5997

Colado MI, Esteban B, O'Shea E, Granados R, Green AR (1999a) Studies on the neuroprotective effect of pentobarbitone on MDMA-induced neurodegeneration. Psychopharmacology 142:421-425

Colado MI, Granados R, O'Shea E, Esteban B, Green AR (1998) Role of hyperthermia in the protective action of clomethiazole against MDMA ('ecstasy')-induced neurodegeneration, comparison with the novel NMDA channel blocker AR-R15896AR. Br J Pharmacol 124:479-484

Colado MI, O'Shea E, Esteban B, Green AR (2001) Studies on the neuroprotective effect of the enantiomers of AR-A008055, a compound structurally related to clomethiazole, on MDMA ("ecstasy")-induced neurodegeneration in rat brain. Psychopharmacol (berl) 157:82-88

Colado MI, O'Shea E, Granados R et al (1999b) Studies on the role of dopamine in the degeneration of 5-HT nerve endings in the brain of Dark Agouti rats following 3,4-methylenedioxymethamphetamine (MDMA or 'ecstasy') administration. Br J Pharmacol 126:911-924

Cole JC, Sumnall HR (2003) Altered states: the clinical effects of Ecstasy. Pharmacol Ther 98:35-58

Coris EE, Ramirez AM, Van Durme DJ (2004) Heat illness in athletes: the dangerous combination of heat, humidity and exercise. Sports Med 34:9-16

Dafters RI (1994) Effect of ambient temperature on hyperthermia and hyperkinesis induced by 3,4-methylenedioxymethamphetamine (MDMA or "ecstasy") in rats. Psychopharmacology $114: 505-508$

Dafters RI (1995) Hyperthermia following MDMA administration in rats: effects of ambient temperature, water consumption, and chronic dosing. Physiol Behav 58:877-882

Dao CK, Nowinski SM, Mills EM (2014) The heat is on: Molecular mechanisms of drug-induced hyperthermia. Temperature (austin) 1:183-191

Davison D, Parrott A (1997) Ecstasy (MDMA) in recreational users: self-reported psychological and physiological effects. Hum Psychopharmacol Clin Exp 12:221-226

De Fanti BA, Gavel DA, Hamilton JS, Horwitz BA (2000) Extracellular hypothalamic serotonin levels after dorsal raphe nuclei stimulation of lean $(\mathrm{Fa} / \mathrm{Fa})$ and obese $(\mathrm{fa} / \mathrm{fa})$ Zucker rats. Brain Res 869:6-14

de la Torre R, Farré M, Roset PN et al (2004) Human pharmacology of MDMA: pharmacokinetics, metabolism, and disposition. Ther Drug Monit 26:137-144

Degenhardt L, Roxburgh A, Dunn M et al (2009) The epidemiology of ecstasy use and harms in Australia. Neuropsychobiology 60:176-187

Desruelle AV, Boisvert P, Candas V (1996) Alcohol and its variable effect on human thermoregulatory response to exercise in a warm environment. Eur J Appl Physiol Occup Physiol 74:572-574

Docherty JR, Green AR (2010) The role of monoamines in the changes in body temperature induced by 3,4-methylenedioxymethamphetamine (MDMA, ecstasy) and its derivatives. Br J Pharmacol 160:1029-1044

Dowling GP, McDonough ET 3rd, Bost RO (1987) 'Eve' and 'Ecstasy'. A report of five deaths associated with the use of MDEA and MDMA. JAMA 257:1615-1617

Dumont GJ, Kramers C, Sweep FC et al (2010) Ethanol co-administration moderates 3,4-methylenedioxymethamphetamine effects on human physiology. J Psychopharmacol 24:165-174
Dumont GJ, Verkes RJ (2006) A review of acute effects of 3,4-methylenedioxymethamphetamine in healthy volunteers. J Psychopharmacol 20:176-187

Eisenhofer G, Johnson RH (1982) Effect of ethanol ingestion on plasma vasopressin and water balance in humans. Amer $\mathbf{J}$ Physiol Reg Integr Comp Physiol 242:R522-R527

Fallon JK, Shah D, Kicman AT et al (2002) Action of MDMA (ecstasy) and its metabolites on arginine vasopressin release. Ann N Y Acad Sci 965:399-409

Faria AC, Carmo, H, Carvalho, F et al (2020) Drinking to death: Hyponatraemia induced by synthetic phenethylamines. Drug Alcohol Depend 212:108045.

Forrest ARW (2003) Rapid response to: Review of deaths related to taking ecstasy, England and Wales, 1997-2000. BMJ 80

Forsling M, Fallon JK, Kicman AT et al (2001) Arginine vasopressin release in response to the administration of 3,4-methylenedioxymethamphetamine ("ecstasy"): is metabolism a contributory factor? J Pharm Pharmacol 53:1357-1363

Freedman RR, Johanson CE, Tancer ME (2005) Thermoregulatory effects of 3,4-methylenedioxymethamphetamine (MDMA) in humans. Psychopharmacol (berl) 183:248-256

Galloway SD (1999) Dehydration, rehydration, and exercise in the heat: rehydration strategies for athletic competition. Can J Appl Physiol 24:188-200

Ghatol A, Kazory A (2012) Ecstasy-associated acute severe hyponatremia and cerebral edema: a role for osmotic diuresis? J Emerg Med 42:e137-140

Ginsberg MD, Hertzman M, Schmidt-Nowara WW (1970) Amphetamine intoxication with coagulopathy, hyperthermia, and reversible renal failure. A syndrome resembling heatstroke. Ann Intern Med 73:81-85

Gordon CJ, Watkinson WP, O'Callaghan JP, Miller DB (1991) Effects of 3,4-methylenedioxymethamphetamine on autonomic thermoregulatory responses of the rat. Pharmacol Biochem Behav 38:339-344

Graham C, Morris NB, Harwood AE, Jay O (2020) Ad libitum water consumption off-sets the thermal and cardiovascular strain exacerbated by dehydration during a 3-h simulated heatwave. Eur J Appl Physiol 120:391-399

Grandjean AC, Reimers KJ, Buyckx ME (2003) Hydration: issues for the 21st century. Nutr Rev 61:261-271

Green AR, O'Shea E, Colado MI (2004a) A review of the mechanisms involved in the acute MDMA (ecstasy)-induced hyperthermic response. Eur J Pharmacol 500:3-13

Green AR, Sanchez V, O'Shea E et al (2004b) Effect of ambient temperature and a prior neurotoxic dose of 3,4-methylenedioxymethamphetamine (MDMA) on the hyperthermic response of rats to a single or repeated ("binge" ingestion) low dose of MDMA. Psychopharmacology 173:264-269

Grunau BE, Wiens MO, Brubacher JR (2010) Dantrolene in the treatment of MDMA-related hyperpyrexia: a systematic review. Can J Emerg Med 12:435-442

Hall AP, Henry JA (2006) Acute toxic effects of "Ecstasy" (MDMA) and related compounds: overview of pathophysiology and clinical management. Br J Anaesth 96:678-685

Hamida S, Plute E, Bach S et al (2007) Ethanol-MDMA interactions in rats: the importance of interval between repeated treatments in biobehavioral tolerance and sensitization to the combination. Psychopharmacology 192:555-569

Hamida SB, Bach S, Plute E et al (2006) Ethanol-ecstasy (MDMA) interactions in rats: preserved attenuation of hyperthermia and potentiation of hyperactivity by ethanol despite prior ethanol treatment. Pharmacol Biochem Behav 84:162-168

Hamida SB, Plute E, Cosquer B et al (2008) Interactions between ethanol and cocaine, amphetamine, or MDMA in the rat: thermoregulatory and locomotor effects. Psychopharmacol (berl) 197:67-82 
Hartung TK, Schofield E, Short AI, Parr MJ, Henry JA (2002) Hyponatraemic states following 3,4-methylenedioxymethamphetamine (MDMA, 'ecstasy') ingestion. QJM 95:431-437

Henry JA (1992) Ecstasy and the dance of death. BMJ 305:5-6

Henry JA, Fallon JK, Kicman AT et al (1998) Low-dose MDMA ("ecstasy") induces vasopressin secretion. Lancet 351:1784

Henry JA, Jeffreys KJ, Dawling S (1992) Toxicity and deaths from 3,4-methylenedioxymethamphetamine ("ecstasy"). Lancet 340:384-387

Herin DV, Liu S, Ullrich T, Rice KC, Cunningham KA (2005) Role of the serotonin 5-HT2A receptor in the hyperlocomotive and hyperthermic effects of (+)-3,4-methylenedioxymethamphetamine. Psychopharmacol (berl) 178:505-513

Het Parool (2019) Duizenden Dam tot Damlopers niet van start [Thousands of "Dam to Dam runners" do not start]. Retrieved 25 May 2021, from https://www.parool.nl/amsterdam/duizenden-damtot-damlopers-niet-van-start bcbc46d8/

Horyniak D, Degenhardt L, Smit de V et al (2014) Pattern and characteristics of ecstasy and related drug (ERD) presentations at two hospital emergency departments, Melbourne, Australia, 2008-2010. Emerg Med J 31:317-322

Huttunen P, Sämpi M, Myllylä R (1998) Ethanol-induced hypothermia and thermogenesis of brown adipose tissue in the rat. Alcohol 15:315-318

Hysek C, Schmid Y, Rickli A et al (2012) Carvedilol inhibits the cardiostimulant and thermogenic effects of MDMA in humans. $\mathrm{Br}$ J Pharmacol 166:2277-2288

Hysek CM, Fink AE, Simmler LD et al (2013) Adrenergic receptors contribute to the acute effects of 3,4-methylenedioxymethamphetamine in humans J Clin Psychopharmacol 33:658-666

Ishiwata T, Hasegawa H, Greenwood BN (2017) Involvement of serotonin in the ventral tegmental area in thermoregulation of freely moving rats Neurosci Lett 6537177

Izco M, Orio L, O'Shea E, Colado MI (2007) Binge ethanol administration enhances the MDMA-induced long-term 5-HT neurotoxicity in rat brain. Psychopharmacology 189:459-470

Kalant H (2001) The pharmacology and toxicology of "ecstasy" (MDMA) and related drugs. Can Med Assoc J 165:917-928

Kalant H, Lê AD (1983) Effects of ethanol on thermoregulation. Pharmacol Ther 23:313-364

Kaye S, Darke S, Duflou J (2009) Methylenedioxymethamphetamine (MDMA)-related fatalities in Australia: demographics, circumstances, toxicology and major organ pathology. Drug Alcohol Depend 104:254-261

Keyes KM, Martins SS, Hasin DS (2008) Past 12-month and lifetime comorbidity and poly-drug use of ecstasy users among young adults in the United States: results from the National Epidemiologic Survey on Alcohol and Related Conditions. Drug Alcohol Depend 97:139-149

Kinner SA, George J, Johnston J, Dunn M, Degenhardt L (2012) Pills and pints: risky drinking and alcohol-related harms among regular ecstasy users in Australia. Drug Alcohol Rev 31:273-280

Kish SJ, Lerch J, Furukawa Y et al (2010) Decreased cerebral cortical serotonin transporter binding in ecstasy users: a positron emission tomography/[(11)C]DASB and structural brain imaging study. Brain 133:1779-1797

Kiyatkin EA, Kim AH, Wakabayashi KT, Baumann MH, Shaham Y (2014) Critical role of peripheral vasoconstriction in fatal brain hyperthermia induced by MDMA (Ecstasy) under conditions that mimic human drug use. J Neurosci 34:7754-7762

Kiyatkin EA, Ren S, Wakabayashi KT, Baumann MH, Shaham Y (2016) Clinically relevant pharmacological strategies that reverse MDMA-induced brain hyperthermia potentiated by social interaction. Neuropsychopharmacol 41:549-559
Leppäluoto J, Vuolteenaho O, Arjamaa O, Ruskoaho H (1992) Plasma immunoreactive atrial natriuretic peptide and vasopressin after ethanol intake in man. Acta Physiol Scand 144:121-127

Liechti ME (2014) Effects of MDMA on body temperature in humans. Temperature (austin) 1:192-200

Liechti ME, Gamma A, Vollenweider FX (2001) Gender differences in the subjective effects of MDMA. Psychopharmacol (berl) 154:161-168

Liechti ME, Kunz I, Kupferschmidt H (2005) Acute medical problems due to Ecstasy use. Case-series of emergency department visits. Swiss Med Wkly 135:652-657

Malberg JE, Seiden LS (1998) Small changes in ambient temperature cause large changes in 3,4-methylenedioxymethamphetamine (MDMA)-induced serotonin neurotoxicity and core body temperature in the rat. J Neurosci 18:5086-5094

Miller DB, O'Callaghan JP (1994) Environment-, drug- and stressinduced alterations in body temperature affect the neurotoxicity of substituted amphetamines in the C57BL/6J mouse. J Pharmacol Exp Ther 270:752-760

Mills EM, Banks ML, Sprague JE, Finkel T (2003) Pharmacology: uncoupling the agony from ecstasy. Nature 426:403-404

Mills EM, Rusyniak DE, Sprague JE (2004) The role of the sympathetic nervous system and uncoupling proteins in the thermogenesis induced by 3,4-methylenedioxymethamphetamine. J Mol Med (berl) 82:787-799

Mitchell JM, Bogenschutz, M, Lilienstein, A et al (2021) MDMAassisted therapy for severe PTSD: a randomized, double-blind, placebo-controlled phase 3 study. Nat Med

Mohamed WM, Ben Hamida S, Cassel JC, de Vasconcelos AP, Jones BC (2011) MDMA: interactions with other psychoactive drugs. Pharmacol Biochem Behav 99:759-774

Montain SJ and Coyle EF (1992) Influence of graded dehydration on hyperthermia and cardiovascular drift during exercise. J Appl Physiol 73:1340-1350

Morefield KM, Keane M, Felgate P, White JM, Irvine RJ (2011) Pill content, dose and resulting plasma concentrations of 3,4-methylendioxymethamphetamine (MDMA) in recreational "ecstasy" users. Addiction 106:1293-1300

Murray R (1996) Dehydration, hyperthermia, and athletes: science and practice. J Athl Train 31:248-252

Nadel ER, Fortney SM, Wenger CB (1980) Effect of hydration state of circulatory and thermal regulations. J Appl Physiol Respir Environ Exerc Physiol 49:715-721

Palamar JJ, Acosta P, Le A, Cleland CM, Nelson LS (2019) Adverse drug-related effects among electronic dance music party attendees. Int J Drug Policy 73:81-87

Papaseit E, Pérez-Mañá C, Torrens M et al (2020) MDMA interactions with pharmaceuticals and drugs of abuse. Exp Opinion Drug Metab Toxicol 16:357-369

Parrott AC (2012) MDMA and temperature: a review of the thermal effects of "Ecstasy" in humans. Drug Alcohol Depend 121:1-9

Parrott AC, Rodgers J, Buchanan T et al (2006) Dancing hot on Ecstasy: physical activity and thermal comfort ratings are associated with the memory and other psychobiological problems reported by recreational MDMA users. Hum Psychopharmacol 21:285-298

Patel MM, Belson MG, Longwater AB, Olson KR, Miller MA (2005) Methylenedioxymethamphetamine (ecstasy)-related hyperthermia. J Emerg Med 29:451-454

Pedersen NP, Blessing WW (2001) Cutaneous vasoconstriction contributes to hyperthermia induced by 3,4-methylenedioxymethamphetamine (ecstasy) in conscious rabbits. J Neurosci 21:8648-8654

Pfennig CL, Slovis CM (2012) Sodium disorders in the emergency department: a review of hyponatremia and hypernatremia. Emerg Med Pract 14:1-26 
Roberts KE (1963) Mechanism of dehydration following alcohol ingestion. Arch Intern Med 112:154-157

Rogers G, Elston J, Garside R et al (2009) The harmful health effects of recreational ecstasy: a systematic review of observational evidence. Health Technol Assess 13:iii-iv, ix-xii, 1-315

Ros-Simó C, Ruiz-Medina J, Valverde O (2012) Behavioural and neuroinflammatory effects of the combination of binge ethanol and MDMA in mice. Psychopharmacology 221:511-525

Rosenberg J, Pentel P, Pond S, Benowitz N, Olson K (1986) Hyperthermia associated with drug intoxication. Crit Care Med 14:964-969

Roxburgh A, Lappin J (2020) MDMA-related deaths in Australia 2000 to 2018. Int J Drug Policy 76:102630

Rubini ME, Kleeman CR, Lamdin E (1955) Studies on alcohol diuresis. I. The effect of ethyl alcohol ingestion on water, electrolyte and acid-base metabolism. J Clin Invest 34:439-447

Rusyniak DE, Ootsuka Y, Blessing WW (2008) When administered to rats in a cold environment, 3,4-methylenedioxymethamphetamine reduces brown adipose tissue thermogenesis and increases tail blood flow: effects of pretreatment with 5-HT1A and dopamine D2 antagonists. Neuroscience 154:1619-1626

Rusyniak DE, Sprague JE (2006) Hyperthermic syndromes induced by toxins. Clin Lab Med 26(165-184):ix

Rusyniak DE, Tandy SL, Hekmatyar SK et al (2005) The role of mitochondrial uncoupling in 3,4-methylenedioxymethamphetaminemediated skeletal muscle hyperthermia and rhabdomyolysis. J Pharmacol Exp Ther 313:629-639

Saadat KS, O'Shea E, Colado MI, Elliott JM, Green AR (2005) The role of 5-HT in the impairment of thermoregulation observed in rats administered MDMA ('ecstasy') when housed at high ambient temperature. Psychopharmacology 179:884-890

Sanchez V, O'Shea E, Saadat KS et al (2004) Effect of repeated ('binge') dosing of MDMA to rats housed at normal and high temperature on neurotoxic damage to cerebral 5-HT and dopamine neurones. J Psychopharmacol 18:412-416

Sawka M, Pandolf, K 1990 Effects of body water loss on physiological function and exercise performance. In: Gisolfi CV, Lamb DR, eds. Perspectives in Exercise Science and Sports Medicine: Fluid homeostasis during exercise. Benchmark Press 3:1-38.

Sawka MN (1992) Physiological consequences of hypohydration: exercise performance and thermoregulation. Med Sci Sports Exerc 24:657-670

Sawka MN, Young AJ, Francesconi RP, Muza SR (1985) Pandolf, KB 1985 Thermoregulatory and blood responses during exercise at graded hypohydration levels. J Appl Physiol 59:1394-1401

Schifano F (2004) A bitter pill. Overview of ecstasy (MDMA, MDA) related fatalities. Psychopharmacology 173:242-248

Schifano F, Oyefeso A, Corkery J et al (2003) Death rates from ecstasy (MDMA, MDA) and polydrug use in England and Wales 19962002. Hum Psychopharmacol 18:519-524

Schürmann L, Croes, E, Vercoulen, E, Valkenberg H (2020) Monitor Drugs Incidents (MDI). Factsheet 2019. Retrieved 20 May 2021, from https://www.trimbos.nl/docs/de825d1b-9742-469e-9d20a1e1fe3ab768.pdf

Schütte JK, Schäfer U, Becker S et al (2013) 3,4-Methylenedioxymethamphetamine induces a hyperthermic and hypermetabolic crisis in pigs with and without a genetic disposition for malignant hyperthermia. Eur J Anaesthesiol 30:29-37

Segar WE, Moore WW (1968) The regulation of antidiuretic hormone release in man: I. Effects of change in position and ambient temperature on blood ADH levels. J Clin Invest 47:2143-2151

Sessa B, Higbed L, O'Brien S et al (2021) First study of safety and tolerability of 3,4-methylenedioxymethamphetamine-assisted psychotherapy in patients with alcohol use disorder. J Psychopharmacol 35:375-383

Shireffs SM and Maughan RJ (1997) Restoration of fluid balance after exercise-induced dehydration: effects of alcohol consumption. J Appl Physiol 83:1152-1158

Skeberdis VA (2004) Structure and function of beta3-adrenergic receptors. Medicina (kaunas) 40:407-413

Sprague JE, Brutcher RE, Mills EM, Caden D, Rusyniak DE (2004) Attenuation of 3,4-methylenedioxymethamphetamine (MDMA, Ecstasy)-induced rhabdomyolysis with alpha1- plus beta3adrenoreceptor antagonists. Br J Pharmacol 142:667-670

Sprague JE, Moze P, Caden D et al (2005) Carvedilol reverses hyperthermia and attenuates rhabdomyolysis induced by 3,4-methylenedioxymethamphetamine (MDMA, Ecstasy) in an animal model. Crit Care Med 33:1311-1316

Sprague JE, Riley CL, Mills EM (2018) Body temperature regulation and drugs of abuse. Handb Clin Neurol 157:623-633

Suy K, Gijsenbergh F, Baute L (1999) Emergency medical assistance during a mass gathering. Eur J Emerg Med 6:249-254

Tao R, Shokry IM, Callanan JJ, Adams HD, Ma Z (2015) Mechanisms and environmental factors that underlying the intensification of 3,4-methylenedioxymethamphetamine (MDMA, Ecstasy)-induced serotonin syndrome in rats. Psychopharmacology 232:1245-1260

Tehan B, Hardern R, Bodenham A (1993) Hyperthermia associated with 3,4-methylenedioxyethamphetamine ('Eve'). Anaesthesia 48:507-510

Topp L, Hando J, Dillon P, Roche A, Solowij N (1999) Ecstasy use in Australia: patterns of use and associated harm. Drug Alcohol Depend 55:105-115

van Amsterdam J, Pennings E, van den Brink W (2020) Fatal and non-fatal health incidents related to recreational ecstasy use. J Psychopharmacol 34:591-599

van Dijken GD, Blom RE, Hené RJ, Boer WH, Consortium N (2013) High incidence of mild hyponatraemia in females using ecstasy at a rave party. Nephrol Dial Transplant 28:2277-2283

Vanattou-Saïfoudine N, McNamara R, Harkin A (2010) Caffeine promotes dopamine D1 receptor-mediated body temperature, heart rate and behavioural responses to MDMA ('ecstasy'). Psychopharmacol (berl) 211:15-25

Vanattou-Saïfoudine N, McNamara R, Harkin A (2012) Caffeine provokes adverse interactions with 3,4-methylenedioxymethamphetamine (MDMA, 'ecstasy') and related psychostimulants: mechanisms and mediators. Br J Pharmacol 167:946-959

Vercoulen E, Hondebrink L (2021) Combining ecstasy and ethanol: higher risk for toxicity? A review. Crit Rev Toxicol 51:1-14

Wasielewski JA, Holloway FA (2001) Alcohol's interactions with circadian rhythms. A focus on body temperature. Alcohol Res Health 25:94-100

Weiner J (1945) The diuretic response of men working in hot and humid conditions. J Physiol 103

Williams H, Dratcu L, Taylor R, Roberts M, Oyefeso A (1998) "Saturday night fever": ecstasy related problems in a London accident and emergency department. J Accid Emerg Med 15:322-326

Winstock AR, Griffiths P, Stewart D (2001) Drugs and the dance music scene: a survey of current drug use patterns among a sample of dance music enthusiasts in the UK. Drug Alcohol Depend 64:9-17

Zhao J, Cannon B, Nedergaard J (1997) alpha1-Adrenergic stimulation potentiates the thermogenic action of beta3-adrenoreceptor-generated cAMP in brown fat cells. J Biol Chem 272:32847-32856

Publisher's Note Springer Nature remains neutral with regard to jurisdictional claims in published maps and institutional affiliations. 